\title{
REAKSI INVESTOR TERHADAP NILAI TAMBAH EKONOMI
}

\author{
ELI ROHMAWATI ${ }^{\mathrm{a}}$ \\ Andry Irawanto ${ }^{b}$ \\ ${ }^{a}$ Sekolah Pascasarjana Universitas Airlangga ${ }^{b}$ Fakultas Ekonomi dan Bisnis Universitas Airlangga \\ Email: elirohmawati@protonmail.com ${ }^{\mathrm{a}}$; andryirwanto149@gmail.com ${ }^{\text {b }}$
}

\section{ARTICLE HISTORY}

Received:

11 July 2018

Revised

10 August 2018

Accepted:

2 September 2018

Online available:

10 November 2018

Keywords:

Economic Value Added

(EVA),

Investor Reaction

Kata Kunci:

Nilai Tambah Ekonomi

(EVA),

Reaksi Investor

\begin{abstract}
Introduction: This study aims to analyze investors' reactions to economic value added (EVA).

Methods: This research uses quantitative methods. The research data was obtained from the Indonesia Stock Exchange and the annual financial reports of sample companies in the 2009-2012 period. Manufacturing companies are used in this study with a sample company of 34 companies.

Results: The results of the study concluded that there was significant investor reaction around the date of the announcement of financial statements on companies that had positive economic value added (EVA) and significantly there were investors' reactions around the date of the announcement of financial statements on companies with negative economic value added (EVA).

Conclusion and suggestion: Further researchers are expected to add other industrial sectors that can apply the EVA concept, and real data in determining the cost of debt (COD)
\end{abstract}




\begin{abstract}
ABSTRAK
Penelitian ini bertujuan untuk menganalisis reaksi investor terhadap nilai tambah ekonomi (EVA). Penelitian ini menggunakan metode kuantitatif. Data penelitian diperoleh dari Bursa Efek Indonesia dan laporan keuangan tahunan perusahaan sampel periode 2009-2012. Perusahaan manufaktur yang digunakan dalam penelitian ini dengan sampel perusahaan sebanyak 34 perusahaan. Hasil penelitian menyimpulkan bahwa terdapat reaksi investor yang signifikan sekitar tanggal pengumuman laporan keuangan pada perusahaan yang memiliki nilai tambah ekonomi (EVA) positif dan secara signifikan terdapat reaksi investor sekitar tanggal pengumuman laporan keuangan pada perusahaan. dengan nilai tambah ekonomi negatif (EVA). Peneliti selanjutnya diharapkan dapat menambah sektor industri lain yang dapat mengaplikasikan konsep EVA, dan data riil dalam penentuan cost of debt (COD).
\end{abstract}

\title{
INTRODUCTION
}

Seiring dengan perkembangan jaman pada dunia usaha menuntut para manajemen untuk menyediakan laporan keuangan yang mengandung informasi yang bisa digunakan sebagai dasar pengambilan keputusan bisnis oleh para investor. Fanani (2008) berpendapat bahwa salah satu elemen penting dalam menilai kinerja perusahaan secara keseluruhan dapat direpresentasikan dalam laba perusahaan yaitu bersumber dari pelaporan keuangan.

Ball and Brown (1968) melakukan penelitian yang secara fundamental menemukan bukti ilmiah bahwa tingkat pengembalian saham perusahaan merespon isi informasi pada laporan keuangan. Penelitian Ball dan Brown merupakan penelitian yang disebut studi peristiwa karena penelitiannya mempelajari reaksi pasar saham atas suatu peristiwa khusus, dalam penelitiannya membahas pengumuman laba bersih tahunan suatu perusahaan. Hasil penelitiannya ditemukan bahwa ada hubungan antara laba akuntansi dan harga saham serta adanya kandungan informasi pada laba.

Ivanov et al. (2014) melakukan penelitian strategi investasi portofolio dengan menggunakan EVA, penelitiannya menunjukkan bahwa portofolio yang dibentuk dengan EVA negatif menghasilkan tingkat pengembalian yang relatif tinggi dibandingkan dengan perusahaan yang memiliki EVA positif.

Pada penelitian sebelumnya secara umum hanya membahas perusahaan yang memiliki nilai tambah ekonomi (EVA) yang positif yang bisa memberikan nilai tambah ekonomi bagi para investor yang dicerminkan dari peningkatan harga saham perusahaan serta merupakan good news bagi para investor, akan tetapi mereka mengabaikan perusahaan yang memiliki nilai tambah ekonomi (EVA) negatif, karena mereka meyakini bahwa perusahaan yang memiliki EVA negatif berarti bahwa perusahaan tersebut memiliki kinerja buruk. 
Pada penelitian ini akan menjelaskan reaksi investor terhadap nilai tambah ekonomi (EVA), bukan hanya dilihat dari nilai tambah ekonomi (EVA) yang bernilai positif, akan tetapi dilihat juga dari segi nilai tambah ekonomi (EVA) yang bernilai negatif selama masa krisis yaitu dilakukan pada tahun 2009-2010. Apakah nilai tambah ekonomi yang bernilai negatif menghasilkan tingkat pengembalian yang positif dan relatif tinggi dibandingkan dengan nilai tambah ekonomi (EVA) positif.

\section{LITERATURE REVIEW}

\section{The traditional society}

\section{Teori Pesinyalan (Signalling Theory)}

Signalling theory adalah teori persinyalan yang menjelaskan bahwa informasi yang dipublikasikan perusahaan merupakan sinyal baik bagi para investor, informasi tersebut dapat digunakan sebagai alat dalam pengambilan keputusan. Informasi yang terkandung dalam laporan keuangan merupakan unsur paling penting bagi investor dan pelaku bisnis karena informasi merupakan penyajian atas informasi yang terkandung dalam laporan keuangan, atau gambaran perusahaan dimasa yang akan datang. Investor menggunakan laporan keuangan yang relevan, akurat dan tepat waktu untuk menganalisis pengambilan keputusan untuk masa yang akan datang. Menurut informasi yang dipublikasikan perusahaan merupakan sinyal yang baik bagi para investor yang dapat digunakan dalam pengambilan keputusan. Jika pengumuman tersebut mengandung nilai positif, diharapkan pasar bereaksi pada waktu pengumuman tersebut diterima oleh pasar.

\section{Teori Efisiensi Pasar}

Hipotesis pasar efisien menyatakan bahwa harga saham sekarang mencerminkan seluruh informasi yang ada, dengan kata lain tidak ada informasi masa lalu yang dapat digunakan untuk memprediksi harga di masa yang akan datang. Secara statistik fenomena pasar efisien dapat digambarkan dengan data yang berdistribusi normal dengan nilai mean dan varian yang stabil. E. Fama (1970) berpendapat bahwa pasar yang efisien adalah pasar dimana harga sekuritas-sekuritasnya mencerminkan secara penuh informasi yang terssedia. Hipotesis pasar efisien menyatakan bahwa tidak ada informasi masa lalu yang dapat digunakan untuk memprediksi pergerakan harga saham dimasa yang akan datang.

\section{Kinerja Keuangan}

Penilaian kinerja adalah salah satu masalah yang paling penting yang dipertimbangkan oleh pemegang saham, kreditur, pemerintah dan manajer yang diberikan kepada pengembangan pasar modal. Investor selalu berniat untuk menyadari tingkat keberhasilan manajer dalam menggunakan modalnya. Keberhasilan atau 
kegagalan manajemen dalam menjalankan tujuan strategi perusahaan, visi, dan misi merupakan gambaran dari kinerja perusahaan. Kinerja merupakan prestasi yang dicapai oleh organisasi perusahaan dalam periode.

\section{Return Saham}

Saham merupakan surat berharga yang menunjukkan kepemilikan atas perusahaan sehingga pemilik saham memiliki hak klaim atas dividen atau distribusi lain yang dilakukan perusahaan kepada pemegang sahamnya, termasuk hak klaim atas aset perusahaan, dengan prioritas setelah hak klaim pemegang surat berharga lain dipenuhi jika terjadi likuiditas. Salah satu motivasi seorang investor dalam melakukan sebuah investasi yaitu untuk dapat menghasilkan keuntungan yang sesuai dengan yang diharapkan yaitu dengan membeli sebagian saham. Hasil dari investasi tersebut yaitu berupa return yang dapat dinikmati oleh pemodal. konsep return merupakan tingkat keuntungan yang dapat dinikmati oleh pemodal atas perilaku investasinya (Ang, 1997).

\section{Previous Study and Hypothesis}

Reaksi investor di sekitar tanggal pengumuman laporan keuangan pada perusahaan yang memiliki nilai tambah ekonomi (EVA) positif. Pada penelitian ini digunakan nilai tambah ekonomi (EVA) sebagai pengukuran kinerja perusahaan, banyak para investor mengetahui apa itu konsep EVA akan tetapi masih jarang perusahaan menggunakan konsep tersebut dan mayoritas perusahaan masih mengukur kinerja perusahaannya menggunakan corporate action. Pada hipotesis ini digunakan teori signaling yang berguna untuk menangkap sinyal-sinyal yang muncul akibat dari reaksi pasar. Ferguson et al (2005) melakukan penelitian dengan menggunakan metodologi event study untuk menyelidiki apakah perusahaan yang mengadopsi system EVA Stern Stewart karena memiliki kinerja yang buruk, dan apakah dengan mengadopsi EVA, perusahaan akan memiliki kinerja yang baik. Ada bukti yang cukup untuk menyimpulkan bahwa perusahaan yang memiliki nilai kinerja yang buruk menyarankan perusahaan untuk mengadopsi EVA, dengan kata lain mengadopsi EVA dapat memperbaiki kinerja perusahaan. Hasil dari penelitian ini menyatakan bahwa perusahaan yang telah mengadopsi EVA mengalami peningkatan profitabilitas yang relatif tinggi dibandingkan dengan rekan mereka yang belum mengadopsi EVA.

$\mathrm{H}_{1}$ : Apakah terdapat reaksi investor terhadap return pada perusahaan yang memiliki nilai tambah ekonomi (EVA) positif?

Reaksi investor di sekitar tanggal pengumuman laporan keuangan pada perusahaan yang memiliki nilai tambah ekonomi (EVA) negatif. Seperti yang dijelaskan oleh Singgih (2008) bahwa jika perusahaan memiliki nilai EVA positif menggambarkan kinerja perusahaan tersebut baik dan mencerminkan tingkat pengembalian yang tinggi dari tingkat biaya modal. EVA yang positif menunjukkan keberhasilan perusahaan dalam menciptakan peningkatan nilai kekayaan perusahaan, dan sebaliknya yang menyiratkan 
bahwa perusahaan gagal dalam menjalankan strategi ataupun tujuan dari perusahaan untuk memaksimalkan keuntungan. Nilai EVA negatif, menunjukkan bahwa laba operasi perusahaan tidak mampu menutupi biaya yang terjadi, menunjukkan bahwa operasi yang dilakukan perusahaan belum sepenuhnya efektif. Jika hal tersebut terus-menerus berkelanjutan, maka perusahaan tidak dapat melanjutkan operasi dan seiring berjalannya waktu maka perusahaan bisa mengalami kebangkrutan. Ivanov et al. (2014) melakukan penelitian strategi investasi portofolio dengan menggunakan EVA, penelitiannya menunjukkan bahwa portofolio yang dibentuk dengan EVA negatif menghasilkan tingkat pengembalian yang relatif tinggi dibandingkan dengan perusahaan yang memiliki EVA positif. Hasil dari penelitiannya menunjukkan bahwa perusahaan portofolio dengan rasio leverage rendah dapat menunjukkan tingkat pengembalian yang lebih tinggi. Selain itu, perusahaan dalam kategori yang didefinisikan sebagai EVA paling negatif dan EVA negatif setidaknya kedua EVA dapat berbalik dan menghasilkan abnormal return yang positif.

$\mathrm{H}_{2}$ : apakah terdapat reaksi investor terhadap return pada perusahaan yang memiliki nilai tambah ekonomi (EVA) negatif?

\section{RESEARCH METHODS}

Populasi penelitian ini adalah seluruh perusahaan manufaktur yang terdaftar di Bursa Efek Indonesia periode 2009-2012 yaitu sebanyak 34 perusahaan manufaktur. Penelitian ini menggunakan data sekunder berupa annual report emiten manufaktur yang listing di Bursa Efek Indonesia selama periode 2008-2012 yang diperoleh dari situs resmi Bursa Efek Indonesia (BEI). Metode yang digunakan dalam pengumpulan data tersebut menggunakan metode dokumentasi.

\section{Nilai Tambah Ekonomi (EVA)}

EVA mengukur nilai tambah yang dihasilkan oleh perusahaan dengan cara mengurangi beban biaya modal (cost of capital) yang timbul sebagai akibat dari investasi yang dilakukan. Berikut merupakan tahap-tahap dalam perhitungan nilai tambah ekonomi (EVA) :

1. Menghitung NOPAT (Net Operating After Tax)

NOPAT = Laba (Rugi) Usaha - Pajak

2. Menghitung Invested Capital (struktur modal)

Invested Capital $=$ (Total Hutang + Ekuitas) - Hutang Jangka Pendek

3. Menghitung WACC (Weighted Average Cost Of Capital)

$W A C C=[(D \times$ rd $)(1-$ tax $)+(E \times$ re $)]$

Dimana :

a. Menghitung Tingkat Bunga

$$
\text { Tingkat Modal }(D)=\frac{\text { Total Hutang }}{\text { Total Hutang }+ \text { Total Ekuitas }} \times 100 \%
$$


b. Cost Of Debt : peneliti menggunakan data prosentase yield to maturity (YTM) bagi perusahaan yang mengeluarkan obligasi, data prosentase hutang jangka panjang bagi perusahaan yang tidak mengeluarkan obligasi, jika perusahaan tidak mengeluarkan obligasi dan tidak memiliki hutang jangka panjang maka cost of debt dapat dilakukan adjustment pada perusahaan sebanding yang memiliki tingkat risiko yang sama ataupun bisa menggunakan $\mathrm{BI}$ rate.

c. Menghitung Tingkat Ekuitas

$$
\text { Tingkat Ekuitas }(E)=\frac{\text { Total Ekuitas }}{\text { Total Hutang }+ \text { Total Ekuitas }} 100 \%
$$

d. Menghitung Cost Of Equity

Perhitungan cost of equity menggunakan market model, dengan menggunakan periode estimasi selama 60 bulan (5 tahun).

4. Menghitung Capital Charges

$$
\text { Tingkat Pajak }=\frac{\text { Beban Pajak }}{\text { Laba Bersih Sebelum Pajak }} \times 100 \%
$$

Rumus:

Capital Charges $=$ WACC $x$ Invested Capital

5. Menghitung Nilai Tambah Ekonomi (EVA)

EVA $=$ NOPAT - Capital Charge

\section{RESULT AND ANALYSIS}

Hasil perhitungan EVA yang dilakukan peneliti memperoleh hasil yang tidak konsisten pada tiap perusahaan dari tahun ke tahun penelitian. Pada tahun penelitian 2009-2012 terdapat 61 perusahaan yang memiliki nilai EVA positif, perusahaan dengan kategori EVA positif maka perusahaan tersebut dapat diberikan poin satu, poin satu dapat menjelaskan bahwa perusahaan tersebut memiliki nilai EVA positif. Pada tahun penelitian 2009-2012 terdapat 75 perusahaan yang memiliki nilai EVA negatif, perusahaan dengan kategori EVA negatif dapat diberikan poin nol, poin tersebut menjelaskan bahwa perusahaan tersebut memiliki nilai EVA negatif. Perusahaan memiliki nilai EVA negatif maka dapat dikatakan bahwa perusahaan tersebut telah gagal dalam melakukan strategi penilaian kinerja perusahaannya dan tidak mendapatkan nilai tambah ekonomi yang diharapkan. EVA negatif merupakan bad news bagi para investor.

Berikut merupakan ringkasan hasil SPSS uji one sample test dan uji T dapat

\begin{tabular}{|c|c|c|c|c|c|c|}
\hline Uji & variabel & Kategori & $\begin{array}{l}\text { Nilai } \\
\text { sign }\end{array}$ & Level & Keterangan & Event window \\
\hline \multirow{5}{*}{$\begin{array}{c}\text { One sample } \\
\text { test }\end{array}$} & \multirow{4}{*}{ AAR } & Positif & 0.097 & \multirow{5}{*}{0.1} & Signifikan & 3 \\
\hline & & & 0.061 & & Signifikan & 0 \\
\hline & & Negatif & 0.094 & & Signifikan & 5 \\
\hline & & & 0.071 & & Signifikan & -4 \\
\hline & CAAR & Positif & 0.061 & & Signifikan & 0 \\
\hline
\end{tabular}
menjelaskan hasil yang diperoleh sebagai berikut: 


\begin{tabular}{|c|c|c|c|c|c|}
\hline & & & 0.097 & Signifikan & -3 \\
\hline & & Negatif & 0.071 & Signifikan & 4 \\
\hline & & & 0.094 & Signifikan & -5 \\
\hline \multirow{4}{*}{ T test } & \multirow{2}{*}{ AAR } & Positif & & \multirow{2}{*}{ Signifikan } & \multirow{2}{*}{-4} \\
\hline & & Negatif & 0.007 & & \\
\hline & \multirow{2}{*}{ CAAR } & Positif & & \multirow{2}{*}{ Signifikan } & \multirow{2}{*}{4} \\
\hline & & Negatif & 0.007 & & \\
\hline
\end{tabular}

Hasil uji one sample test didapatkan hasil bahwa secara signifikan investor bereaksi pada penerbitan laporan keuangan di periode event window yang telah ditentukan sebelumnya baik untuk average abnormal return (AAR) dan cumulative average abnormal return (CAAR) pada level signifikansi 0.1 (10\%) pada perusahaan yang memiliki nilai EVA positif ataupun pada perusahaan yang memiliki nilai EVA negatif. Sedangkan pada uji T didapatkan hasil secara signifikan investor juga bereaksi pada penerbitan laporan keuangan di periode event window yang telah ditentukan sebelumnya baik pada perusahaan yang memiliki nilai EVA positif ataupun pada perusahaan yang memiliki nilai EVA negatif. Pada hasil ini bisa menjelaskan bahwa pada perusahaan masih bisa memberikan return yang positif meskipun nilai yang dihasilkan tidak terlalu besar.

Hasil penelitian yang diperoleh bahwa investor bereaksi pada penerbitan laporan keuangan pada event window dapat menjelaskan bahwa secara teori persinyalan investor menangkap sinyal-sinyal yang telah diinformasikan perusahaan, informasi tersebut dapat digunakan sebagai alat dalam pengambilan keputusan. Investor beraksi pada saat diterbitkannya laporan keuangan $\left(\mathrm{t}_{0}\right)$ menyiratkan bahwa investor hanya melihat laporan keuangan yang diterbitkan pada saat itu tanpa menganalisisnya terlebih dahulu, selanjutnya apabila investor bereaksi pada hari sebelum diterbitkannya laporan keuangan menyiratkan bahwa adanya kebocoran informasi perusahaan yang bersangkutan kepada publik, selanjutnya ketika investor yang bereaksi pada hari setelah diterbitkannya laporan keuangan menyiratkan bahwa investor tersebut menganalisis laporan keuangan yang diterbitkan sebelum investor tersebut melakukan investasi pada perusahaan yang bersangkutan.

Pada efisiensi pasar setengah kuat terdapat dua kategori yaitu pasar efisiensi bentuk setengah kuat yang berdasarkan informasi yang dipublikasikan yang biasa disebut dengan efisiensi pasar secara informasi dan efisiensi pasar bentuk setengah kuat yang berdasarkan keputusan. Pada efisiensi pasar keputusan terdapat investor yang canggih yang dapat membedakan pengumuman yang bernilai ekonomis dan yang tidak bernilai ekonomis, investor yang canggih dapat menganalisis lebih dalam informasi yang diterima agar terhindar dari kebohongan atas informasi yang dipublikasikan oleh 
perusahaan sehingga investor tidak akan mengalami kerugian atas investasi kosong. Pasar efisiensi bentuk setengah kuat secara informasi belum tentu efisiensi secara keputusan, pasar efisiensi secara keputusan juga merupakan pasar yang efisien secara informasi. Penelitian ini juga membuktikan penelitian fundamental yang dilakukan Ball and Brown (1968) menemukan bukti ilmiah bahwa tingkat pengembalian saham perusahaan merespon isi informasi pada laporan keuangan.

Para investor dalam mengestimasi nilai yang diharapkan dan resiko pengambilan sekuritas sangat membutuhkan informasi akuntansi. Pelaporan keuangan dinilai dari kualitas informasi yang dilaporkan dapat meningkatkan efisiensi dengan pengurangan asimetri informasi yang menimbulkan pergeseran ekonomi seperti bahaya moral dan seleksi yang merugikan (Biddle et al., 2009). Informasi mengandung nilai jika informasi tersebut dapat merubah reaksi investor yang dapat dicerminkan melalui perubahan harga saham yang dapat diukur dengan abnormal return serta jumlah transaksi yang diukur melalui trading volume activity (TVA).

Hasil penelitian ini menjelaskan bahwa perusahaan yang menghasilkan nilai EVA positif dapat memberikan good news bagi para investor sebagai nilai tambah untuk memperoleh imbal hasil yang diinginkan oleh para investor, begitu juga pada perusahaan yang memiliki nilai EVA negatif, pada penelitian ini perusahaan yang memiliki nilai EVA negatif juga bisa mempengaruhi investor bereaksi pada penerbitan laporan keuangan ini ditunjukkan pada hasil uji $\mathrm{T}$ test yaitu investor bereaksi pada penerbitan laporan keuangan disekitar tanggal pengumuman laporan keuangan. Hasil penelitian ini menyiratkan bahwa investor tidak membedakan antara perusahaan yang memiliki nilai EVA positif atau perusahaan yang memiliki EVA negatif.

Secara keseluruhan dari hasil penelitian ini mendukung penelitian yang dilakukan oleh Ivanov et al (2014) dengan hasil penelitian bahwa perusahaan dengan nilai EVA negatif bisa memberikan tingkat pengembalian yang positif, ini ditunjukkan dengan hasil uji one sample test dan uji $\mathrm{T}$ bahwa investor bereaksi disekitar tanggal penerbitan laporan keuangan pada perusahaan yang memiliki nilai EVA positif ataupun pada perusahaan yang memiliki nilai EVA negatif. Perkembangan dunia usaha global yang semakin kompetitif mempengaruhi kondisi perekonomian suatu negara. Persaingan global yang sedemikian ketatnya mendorong pemerintah untuk lebih memperhatikan berbagai aspek, khususnya aspek ekonomi. Begitu juga dengan pelaku usaha agar lebih aktif dalam menghadapi globalisasi untuk menarik investor domestik dan mancanegara. Krisis moneter yang melanda Indonesia sampai sekarang telah memporakporandakan perekonomian Indonesia yang semula mengalami pertumbuhan ekonomi yang pesat, sehingga menimbulkan terjadinya inflasi. Akibat inflasi yang terus menerus meningkat dan peningkatannya tidak dapat dikendalikan, membuat semua bidang ekonomi terkena 
imbasnya. Khususnya pada pasar modal, harga saham mengalami fluktuasi yang begitu besar.

\section{CONCLUSION}

Kesimpulan dari penelitian ini adalah baik perusahaan yang memiliki nilai tambah ekonomi (EVA) positif ataupun perusahaan yang memiliki nilai tambah ekonomi (EVA) negatif masih memiliki daya tarik terhadap investor, pada hasil penelitian ini yang ditunjukkan pada $T$ test atas AAR, investor bereaksi pada hari ketiga setelah penerbitan laporan keuangan, dan T test atas CAAR investor bereaksi pada hari ketiga sebelum diterbitkannya laporan keuangan.

Ada beberapa keterbatasan dalam penelitian ini diantaranya adalah, peneliti hanya menggunakan satu jenis perusahaan yaitu perusahaan yang bergerak dibidang manufaktur yang terdaftar di Bursa Efek Indonesia, perusahaan manufaktur memiliki ekspansi pasar yang luas serta pada penerapan EVA tidak semua perusahaan dapat diterapkan karena EVA berkaitan erat dengan biaya hutang, pastinya pada sektor perusahaan non keuangan tidak dapat menerapkan EVA. Pada perhitungan cost of debt (COD) peneliti menggunakan data prosentase yield to maturity (YTM) bagi perusahaan yang mengeluarkan obligasi, data prosentase hutang jangka panjang bagi perusahaan yang tidak mengeluarkan obligasi, jika perusahaan tidak mengeluarkan obligasi dan tidak memiliki hutang jangka panjang maka cost of debt dapat dilakukan adjustment pada perusahaan sebanding yang memiliki tingkat risiko yang sama ataupun bisa menggunakan $\mathrm{BI}$ rate. Cost of debt dijadikan keterbatasan dikarenakan adanya percampuran antara perusahaan yang mengeluarkan obligasi ataupun tidak mengeluarkan obligasi, seharusnya ada spesifikasi antar perusahaan yang mengeluarkan obligasi dan tidak menggunakan asumsi tapi data riil yang akan digunakan.

Ada beberapa saran yang harus dipertimbangkan oleh peneliti selanjutnya untuk melanjutkan hasil penelitian ini diantaranya adalah peneliti selanjutnya diharapkan menambahkan sektor industri lain yang bisa menerapkan konsep EVA, agar hasil yang diperoleh bisa diaplikasikan untuk semua perusahaan dan merupakan tujuan dari penelitian kuantitatif adalah bisa memberikan hasil penelitian yang dapat digeneralisai untuk semua sampel. Peneliti selanjutnya diharapkan bisa memperoleh data riil dalam penentuan cost of debt (COD), sehingga hasil yang diperoleh sesuai dengan reaksi pasar yang berlaku. 


\section{REFERENCES}

Ang, Robert. 1997. Buku Pintar Pasar Modal Indonesia. Jakarta Mediasoft Indonesia. Ball, R. dan Brown, P. 1968. An Empirical Evaluation of Accounting Income Numbers. Journal of Accounting Research, August, 159-178.

Beaver, W. 1968a. The Information Content of Annual Earnings Announcements. Journal of Accounting Research, Suplement 6, 67-92.

Beaver, W. 1968b. The Information Content of Annual Earnings Announcements. . Journal of Accounting Research, Suplement 6, 67-92.

Biddle, Gary, Hillary dan Verdi. 2009. How does financial reporting quality relate to invesment efficiency? Journal of Accounting and Economic, 48 (2-3), 112-131.

Biddle, Gary, Hillary danVerdi. 2009. How does financial reporting quality relate to invesment efficiency? Journal of Accounting and Economic, 48 (2-3): 112-131.

Brigham, Eugene F. dan Houston, Joel F. 2006. Dasar-Dasar Manajemen Keuangan. Jakarta: PT. Salemba Empat.

Carrillo, Constanza dan Nino, Jorge. 2006a. EVA's information content : interpretation and empirical evidence from Chile. Revista Latinoamericana de Administracion Academia 36, 1-23.

Carrillo, Constanza dan Nino, Jorge. 2006b. EVA's information content: interpretation and empirical evidence from Chile. Academia, Revista Latinoamericana de Administración, 36, 1-23.

Chandrasari, Ratna dan Zurotun. 2006. Keinformatifan Laba di Pasar Obligasi dan Saham: Uji Liqudation Option Hyphotesis. Simposium Nasional Akuntansi IX. Padang. Fama, E. F. dan Blume, M. 1966. Filter Rules and Stock Market Trading. Journal of Bussiness, No. 39, 226-241.

Fama, Eugene. 1970. Efficient Capital Markets - A review of theory and empirical work. Journal of Finance Vol 25, No. 2.

Fanani, Zaenal. 2008. Kualitas Pelaporan Keuangan: Faktor-faktor Penentu dan Konsekuensi Ekonominya. The 2nd Accounting Conference, 1st Doctoral Colloquium, and Accounting Workshop Depok.

Foster, Gorge. 1986. Financial Accounting Theory. New Jersey: Prentice-Hall Englewood Cliffs.

Hartono, Jogiyanto. 2000. Teori Portofolio dan Analisis Investasi. Yogyakarta: BPFEUGM.

Hartono, Jogiyanto. 2003. Teori Portofolio dan Analisa Investasi. Yogyakarta: BPFE.

Huang, Chunghuey dan Wang, Mao-Chang. 2008. The Effects of Economic Value Added and Intellectual Capital on the Market Value of Firms: An Empirical Study. International Journal of Management, Vol. 25 No. 4 722-731.

Husnan, Suad. 2005. Teori Portofolio dan Analisis Sekuritas. Yogyakarta

UPP AMP YKPN.

Ivanov, Stoyu I., Leong, Kenneth dan Zaima, Janis K. 2014. An Empirical Examination Of Negative Economic Value Added Firms. The International Journal of Business and Finance Research 8.

SAK, Standar Akuntansi Keuangan 2009. Standar Akuntansi Keuangan Per 1 Juli 2009. Jakarta: Penerbit Salemba Empat. 
Samsul. 2006. Pasar Modal dan Manajemen Portofolio. Jakarta: Erlangga.

Singgih, M.L. . 2008. Pengukuran Kinerja Perusahaan Dengan Metode Economic Value Added. ITS Surabaya: Fakultas Teknologi Industri.

Stewart, Stern. 1993. The Stern Stewart Performance 1000: a Guide to Value-added Performance; 1982-1991. Statistical Review [M] New York, NY,.

Sumarwoto. 2007. Pengaruh Kebijakan Rotasi KAP terhadap Kualitas Laporan Keuangan.

Tandelilin, Eduardus. 2001. Analisis Investasi dan Manajemen Portofolio. Yogyakarta: BPFE.

Xin, Zhao, Ting, Wang danYuana, Zheng. 2012. Economic Value Added for Performance Evaluation: a Financial Engineering. Systems Engineering Procedia, 5, 379-387.

Young, S. David danO'Byrne, Stephen F. 2001. EVA and Value Based Management: $A$ Practical Guide to Implemenlation. USA: McGraw-Hill Companies, Inc. 